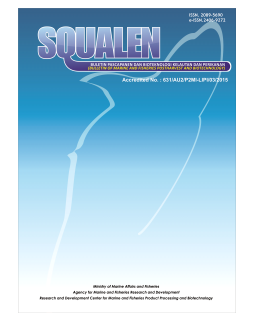

\title{
ALGINATE LYASE FROM INDONESIAN Bacillus megaterium S245 SHOWS ACTIVITIES TOWARD POLYMANNURONATE AND POLYGULURONATE
}

\author{
Subaryono', Yuwanita Ardilasari², Rosmawaty Peranginangin'1, Fransisca Rungkat Zakaria ${ }^{2}$, \\ and Maggy Thenawidjaja Suhartono ${ }^{*}$ \\ ${ }^{1}$ Research and Development Center for Marine and Fisheries Product Competitiveness and Biotechnology \\ Jalan KS Tubun Petamburan VI, Central Jakarta, Indonesia 10260; \\ ${ }^{2}$ Departement of Food Science and Technology, Bogor Agriculture University, JI. Raya Dramaga, Kampus IPB, Bogor, \\ Indonesia 16680 \\ Article history: \\ Received: 15 May 2016; Revised: 3 July 2016; Accepted: 25 July 2016
}

\begin{abstract}
Screening of alginate lyase producing bacteria associated with seaweed Sargassum crassifolium was carried out, and isolate S245, identified as Bacillus megaterium S245 was found to produce high alginate lyase activity. This research was conducted to evaluate activity of the alginate lyase enzyme at various pHs, temperatures and substrates. Polymannuronate and polyguluronate were used to evaluate substrate specificities. Alginate lyase activity was assayed by analysis of reducing sugar released using the 3,5 dinitrosalicylic acid (DNS) method. The research showed that the activity of alginate lyase was optimum at pH of 7.0 and temperature of $45^{\circ} \mathrm{C}$. This enzyme was active for both polymannuronate and polyguluronate susbtrates. The $\mathrm{V}_{\max }$ and $\mathrm{K}_{\mathrm{m}}$ of this enzyme for polymannuronate and polyguluronate were $200 \mathrm{unit} / \mathrm{ml} / \mathrm{min}$ and $79.8 \mathrm{mg} / \mathrm{ml}$ for polymannuronate substrate and $27.78 \mathrm{unit} / \mathrm{ml} / \mathrm{min}$ and $13.17 \mathrm{mg} / \mathrm{ml}$ for polyguluronate substrate. This enzyme showed unique characteristic in working toward the two substrates.
\end{abstract}

Keywords: alginate lyase, seaweed, Bacillus, kinetic activity, Sargassum sp.

\section{Introduction}

Alginate lyase or alginase (EC4.2.2.3 and EC4.2.2.11), an enzyme that catalyze the degradation of alginate by a $\beta$-elimination mechanism has been isolated from various sources, such as soil bacteria, marine bacteria, marine mollusks and crustaceae, brown seaweed and fungi (Guan, Wang \& Guo, 2011 Li et al., 2011a; Li, Jiang, Matiur, Ling, Akira \& Takao, 2012; Subaryono, Peranginangin, Suhartono \& Zakaria, 2013). The alginases from alginolytic bacteria, included those of soil and marine bacteria have been isolated from Pseudomonas sp. QD03 (Xiao, Han, Yang, Xin-zhi and Wen-gong, 2006), Pseudoalteromonas atlantica AR06 (Matsushima et al., 2010), Pseudoalteromonas sp. SM0524 (Li et al., 2011'a), Pseudomonas fluorescens HZJ216 (Li, Jiang, Guan, Wang \& Guo, 2011 ${ }^{\mathrm{b}}$ ), Stenotrophomas maltophilia KJ-2 (Lee, Choi, Lee \& Kim, 2012), Bacillus subtitlis (El Ahwany \& Elborai, 2012), and Flavobacterium sp. S20 (Lishuxin, Jungang, Qiang,
Hong \& Yuguang, 2013). Based on their substrate specificity, alginate lyases are classified into poly ( $\beta$ D-mannuronate) lyases (EC4.2.2.3) and poly ( $\alpha$-Lguluronate) lyases (EC 4.2.2.11). Examples of alginate lyases with poly ( $\beta$-D-mannuronate) as substrate are produced from Azotobacter chroococcum (Khanafari \& Sepahei, 2007), Azotobacter vinelandii (Gimmestad et al., 2009), Littorina spp (Matiur, Ling, Akira \& Takao, 2012), and Pseudomonas aeruginosa (Rasamivaraka, Labtani, Duez \& Jaziri, 2015). On the oher hand, alginate lyase from Klebsiella pneumoniae (Baron et al., 1994), Vibrio sp. 510 (Hu, Jiang \& Hwang, 2006) and Enterobacter cloacae WD 7 (Prasertsan, Wichienchot, Doelle \& Kennedy, 2008), showed specificity toward poly ( $\alpha$-L-guluronate) lyases. Another alginate lyase with the two substrates specificity were produced by $P$. alginovora strain $\mathrm{XO} 17$ and Sphingomonas sp. strain A1. Hashimoto, Miyake, Momma, Kawai and Murata (2000) also reported alginate lyase from soil bacteria Sphingomonas sp.

\footnotetext{
${ }^{*}$ Corresponding author.

E-mail: mthenawidjaja@yahoo.com
} 
strain $A 1$ which has activities both on polymannuronate and polyguluronate.

Alginate lyase has been used in many applications such as in producing poly (M) and poly (MG) blocks (Wong, Preston \& Shiller, 2000), to degrade alginate in wakame composting process (Tang, Taniguchi, Chu, Zhou \& Nagata, 2009), to produce bioactive oligosaccharide (An et al., 2009; Guo et al., 2011; Iwamoto, Araki, Iriyama, Oda, Fukuda \& Hayashida, 2005) and to analyze alginate fine structure (Kim, Lee \& Lee, 2011). Since many bioactive molecule can be produced using alginate lyase, the future application of this enzyme will continue to increase (Wong, Preston \& Shiller, 2000). We had isolated bacteria that produce alginate lyase from decomposting seaweed S. crassifolium and found that isolate S245 has the highest lyase activity compared to other isolates. This enzyme has activities on both polymannuronate and polyguluronate substrate (Subaryono, Peranginangin, Suhartono \& Zakaria, 2013). Considering the potential aplication of this enzyme to produce bioactive alginate oligosaccharides, it is important to find identity of this bacteria and the enzyme characteristics. This is done to get the source of alginate lyase-producing bacteria that safe as well as to optimize the application of alginate lyase on the production of alginate oligosaccharides enzymatically. The objective of this study was to identify alginolytic isolat S245, the effect of $\mathrm{pH}$, temperature and substrates on the enzyme activities.

\section{Material and Methods}

\subsection{Material}

Bacteria S245 was previously isolated from decomposing seaweed of $S$. crassifolium from Binuangeun Water, Province of Banten, Indonesia. The procedure of isolation of this bacteria was reported earlier (Subaryono et al., 2013). The isolate was kept alive in luria bertani agar medium containing $1 \%$ of sodium alginate (Sigma Inc.) Other chemicals were purchased form Merck through local distributors.

\subsection{Bacteria Identification}

Bacteria identification was conducted by morphological, biochemical and molecular analysis. Morphology of bacteria was observed under microscope after Gram staining and spore staining. Bacteria identification using biochemical reaction was conducted to the 24 hours age of isolate using API ${ }^{\circledR}$ bacterial kit identification. Molecular identification of bacteria was conducted with $16 S$ rDNA sequencing.
The $16 \mathrm{~S}$ ribosomal DNA analysis was carried out with several steps. The bacteria was first incubated for 24 hours, and then DNA extraction was carried out using a Genomic DNA Purification Kit (Fermentas Life Bioscience, EU). The primers used to amplify the $16 S$ rDNA fragment were 63f (5'-CAGGCCT AACAC AGGCAAGTC) and 1387r (5'GGG CGGW GT GTACAAGGC). PCR was carried out by using a GeneAmp PCR System 9700 (Applied Biosystem, Foster City, CA, USA) with the following conditions for amplification : initial denaturation at $95{ }^{\circ} \mathrm{C}$ for 5 $\mathrm{min}, 30$ cycles of $1 \mathrm{~min}$ of denaturation at $95^{\circ} \mathrm{C}, 1$ min of annealing at $56^{\circ} \mathrm{C}$, and $1.5 \mathrm{~min}$ of extension at $72^{\circ} \mathrm{C}$, and final extension at $72^{\circ} \mathrm{C}$ for $7 \mathrm{~min}$. The $16 \mathrm{~S}$ rDNA sequence was blasted and aligned with multiple sequence data in GenBank database by using BLAST algorithm and CLUSTALW program. The phylogenetic three was constructed by using neighbor-joining algorithm.

\subsection{Enzyme Production}

The bacteria were cultured in Luria Bertani medium containing alginate (Merck Milipore, 71753) $5 \mathrm{mg} / \mathrm{ml}$ $(\mathrm{w} / \mathrm{v})$ at $30^{\circ} \mathrm{C}$ for 48 hours on a stagnant culture. The culture was then centrifuged at $10,000 \times \mathrm{g} 4^{\circ} \mathrm{C}$ for 20 minutes and supernatant containing alginate lyase was concentrated using amonium sulphate precipitation. To the supernatant, ammonium sulphate was added until concentration of $35 \%(\mathrm{w} / \mathrm{v})$, stired at cold temperaturs for 2 hours and centrifugated at 10,000 $\mathrm{x}$ $\mathrm{g}$ for 20 minutes. The pellet was dialyzed againts 20 $\mathrm{mM}$ sodium phosphate buffer $(\mathrm{pH} 7.0)$ at $4{ }^{\circ} \mathrm{C}$ for 24 hours to produce crude enzyme.

\subsection{Enzyme Activity Asay}

Polymannuronate and polyguluronate were prepared from alginate using method of Haug, Larsen \& Smidsrød (1967). Briefly, alginate is dispersed in $500 \mathrm{ml} 0.3 \mathrm{M} \mathrm{HCl}$, and kept in a water bath $100^{\circ} \mathrm{C}$ for 5 hours. The solution was then cooled and centrifuged at $4500 \mathrm{xg}$ for 10 minutes. The supernatant was removed, and the precipitate containing $M$ and $G$ block was resuspended in aquadest. $\mathrm{pH}$ was adjusted to 2.8 using $5 \mathrm{M} \mathrm{NaOH}$ solution, and let stand for 24 hours. After centrifuged at $4500 \mathrm{xg}$ for 10 minutes, the supernatant containing $M$ blocks was neutralized, dialyzed and freeze-dried. The insoluble part which is $G$ blocks was also neutralized, dialyzed and freezedried (Haug, Larsen \& Smidsrød, 1967).

The reducing sugar produced by enzyme substrate reaction was detected using the 3,5-dinitrosalicylic acid (DNS) method following Tang et al. (2009) with slight modification. $1 \mathrm{ml}$ of sample mixture at $(0,8 \mathrm{ml}$ 
sodium phosphate buffer $+0.1 \mathrm{mg}$ alginate $+0.1 \mathrm{ml}$ enzyme) was mixed with $1 \mathrm{ml}$ of DNS solution and boiled for $5 \mathrm{~min}$. Absorbance of the reaction solution was observed at $540 \mathrm{~nm}$. Standard curve with mannose at concentration of $0.1,0.3,0.5,0.7$ and $0.9 \mathrm{mg} / \mathrm{ml}$ followed the same steps. Enzyme activity was expressed as enzyme that released 1 ug reducing sugar per minute per $\mathrm{ml}$ of enzyme under that condition.

\subsection{Enzyme Characterization}

To study the activity of alginate lyase at different $\mathrm{pH}$, as much as $0.8 \mathrm{ml}$ universal buffer $(\mathrm{pH} 6-11)$ was mixed gently with $0.1 \mathrm{ml} 1 \%$ alginate solution and $0.1 \mathrm{ml}$ of enzyme. The mixture was incubated at $30{ }^{\circ} \mathrm{C}$ for 30 minute, and enzyme reaction was stopped by heating $10 \mathrm{~min}$ in boiled water. To study the effect of temperature on lyase activity, the same mixture was made and incubated at various temperature: of $25,35,45,65,75$ and $85^{\circ} \mathrm{C}$ for 30 minutes. To study the substrate specificities, the alginate solution was replaced by polymannuronate at concentration of 1.0 , $7.5,15.0,30.0,60.0$ and $120.0 \mathrm{mg} / \mathrm{ml}$ and polyguluronate at concentration of $0.5,1.0,2.5,5.0$, $7.5,15.0$, and $30.0 \mathrm{mg} / \mathrm{ml}$. The activity of alginate lyase was assayed after the treatment by measuring the released reducing sugar using DNS method. The kinetics curves were drawn by Lineweaver-Burk double reciprocal plot method, and the $\mathrm{K}_{\mathrm{m}}$ and $\mathrm{V}_{\text {max }}$ were determined.

The activity staining assay was performed according to the method Kawamoto et al. (2006) with some modifications. Enzyme was separated using
$15 \%$ (w/v) SDS-PAGE without merchaptoethanol, and the gel was renaturated three times for 30 minutes incubations in a renaturation buffer $(50 \mathrm{mM}$ Tris- $\mathrm{HCl}$ buffer [pH 8.0], $10 \mathrm{mg} / \mathrm{ml}$ of casein, $2 \mathrm{mM}$ EDTA, $0.01 \%$ $\mathrm{NaN}^{3}$ ) containing $25 \%$ of methanol. The gel was overlayed on a $1 \%$ agar gel containing $1 \mathrm{mg} / \mathrm{ml}$ of sodium alginate, $10 \mathrm{mg} / \mathrm{ml}$ of $\mathrm{NaCl}$, and $100 \mathrm{mM}$ Tris$\mathrm{HCl}$ buffer $(\mathrm{pH} 7.2)$, and incubated at $30^{\circ} \mathrm{C}$ for 20 hours. Visualization of clear zone was conducted with addition of $10 \% \mathrm{CaCl}_{2}$ for 30 minutes.

\section{Results and Disucssion}

\subsection{Bacterial Identification}

Microscopic examination of isolate S245 indicated a Gram-positive bacteria, rod shape and spore producing as seen in Figure 1. Biochemical analysis of the bacteria showed positive result for Gram, calatase, oxidase, gelatin, glucose, saccharose, meleztebiose and amylase. Negative result was shown for arginine dihyrolase (ADH), lysine decarboxylase (LDC), ornithine decarboxylase (ODC), citrate reductase, $\mathrm{H}_{2} \mathrm{~S}$ reductase, urea, tryptophane deaminase (TDA) and indole. The positive catalase of the isolate showed that this bacteria can survive in aerobic condition, such as in their natural habitate (marine water agitated with sea wave). This bacteria also showed positive oxidase, that mean posessing cytochrome oxidase as a specific characteristic for aerob or facultative anaerob organism (Trivedi, Pandey \& Bhadauria, 2010). From the ability to metabolize carbohydrate, it can be seen that these bacteria were able to utilize glucose, saccharose, meltobiose, and a

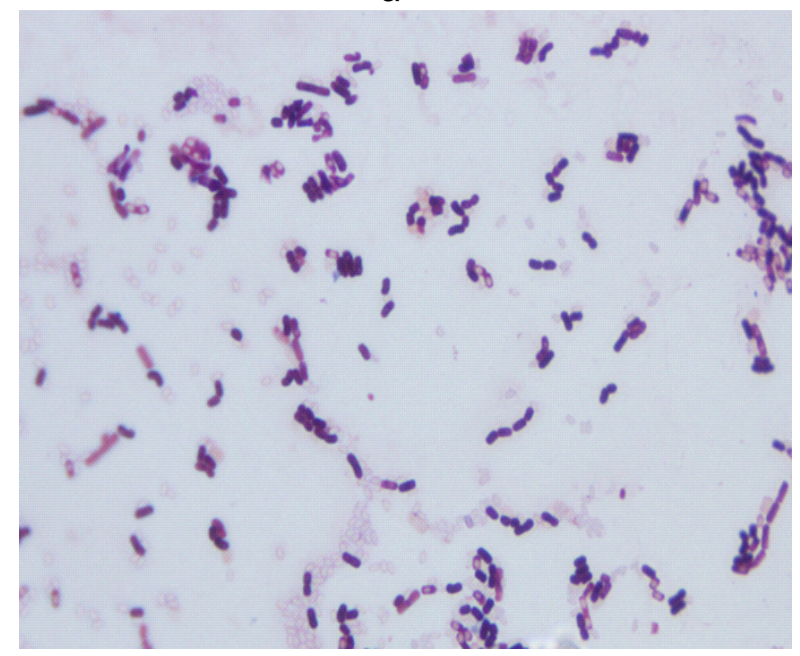

b

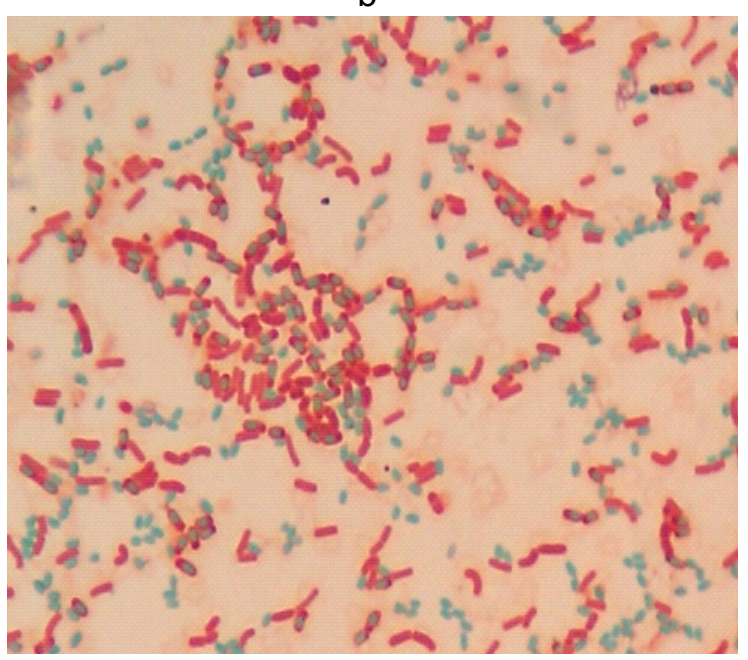

Figure 1. Isolate S245 under microscope after Gram staining (a) and spora staining (b) (magnifications 1000 x). 


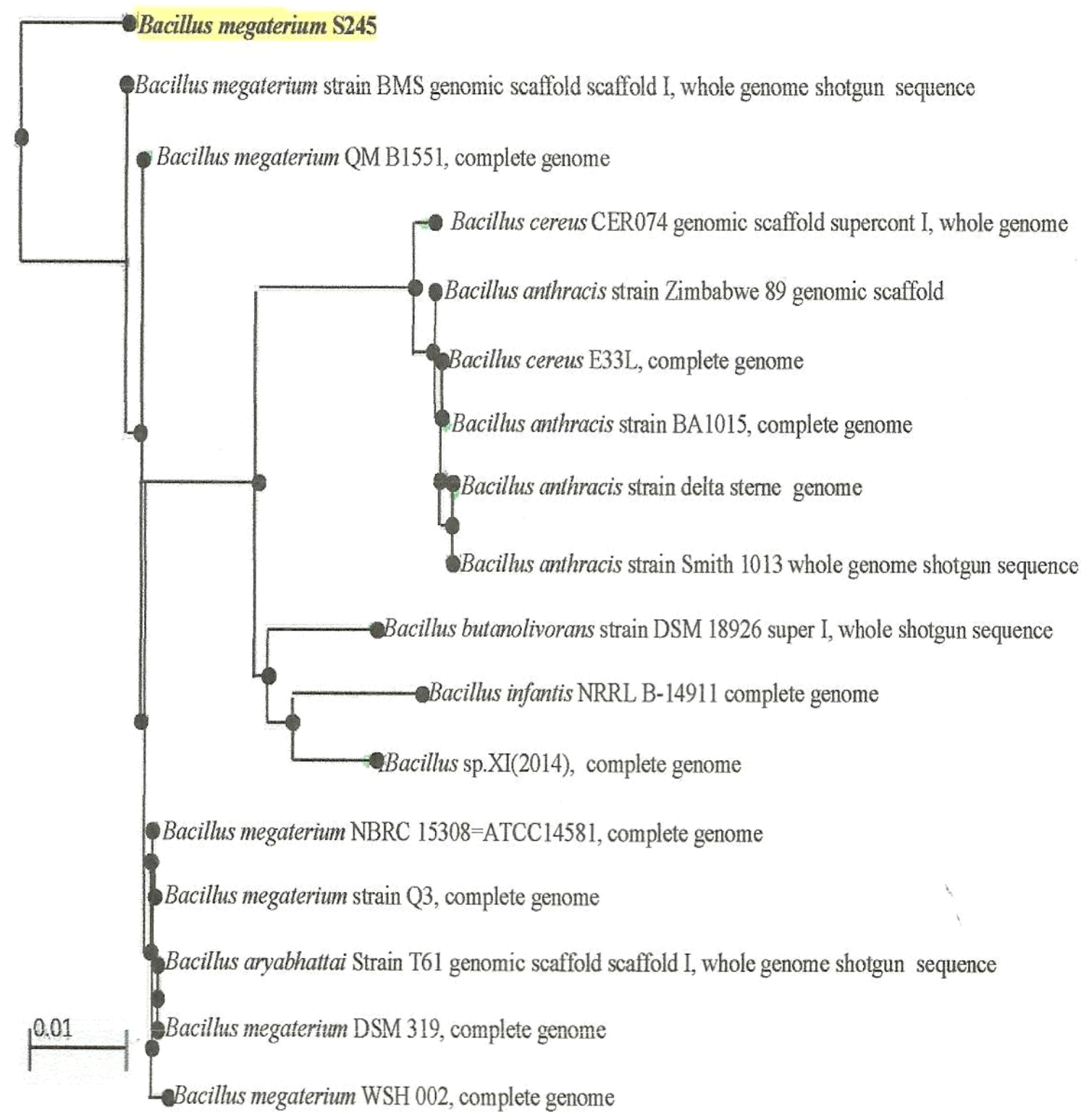

Figure 2. Phylogenetic three based on $16 \mathrm{~S}$ rRNA of $B$. megatrerium S245 and other related species.

amylum. It can be concluded that alginate was not the only carbon source for this bacteria. From biochemical analysis result (using API kit bacteria identification) the $\mathrm{S} 245$ isolate was closely related to B. megaterium (ID 85\%).

Partial 16S rDNA analysis suggested that S245 was most closely related to $B$. megaterium DSM 319 (96\% similarity), B. megaterium QM B1551 (96\% similarity), B. megaterium WSH 002 (96\% similarity), Bacillus sp. 1NLA3E (94\% similarity), B. infantis NRRL B-14911 (94\% similarity) and relatively close to other species of Bacillus. Therefore, S245 is a strain of genus Bacillus and we identified this as $B$. megaterium S245. Bacillus species such as $B$. megaterium was commonly found in soil, sea water, sediment, or decomposing material (Scholle, White, Kunnialaiyaan \& Vary, 2003). The phylogenetic tree of this bacteria was shown in Figure 2.

Previous studies reported that marine bacteria producing alginate lyase were Alteromonas sp. strain H-4 (Sawabe, Otsuka \& Ezura,1997), Vibrio sp. O2 (Kawamoto et al., 2006), Pseudoalteromonas agarovans (Choi, Piao, Shin \& Cho, 2009), Pseudoalteromonas atlantica AR06 (Matsushima et al., 2010), and Pseudomonas fluorescens HZJ216 (Li et al., 2011 $)$. On the other hand, alginate lyase reported from soil bacteria were Corynebacterium sp (Matsubara, Iwasaki \& Muramatsu, 1998), 

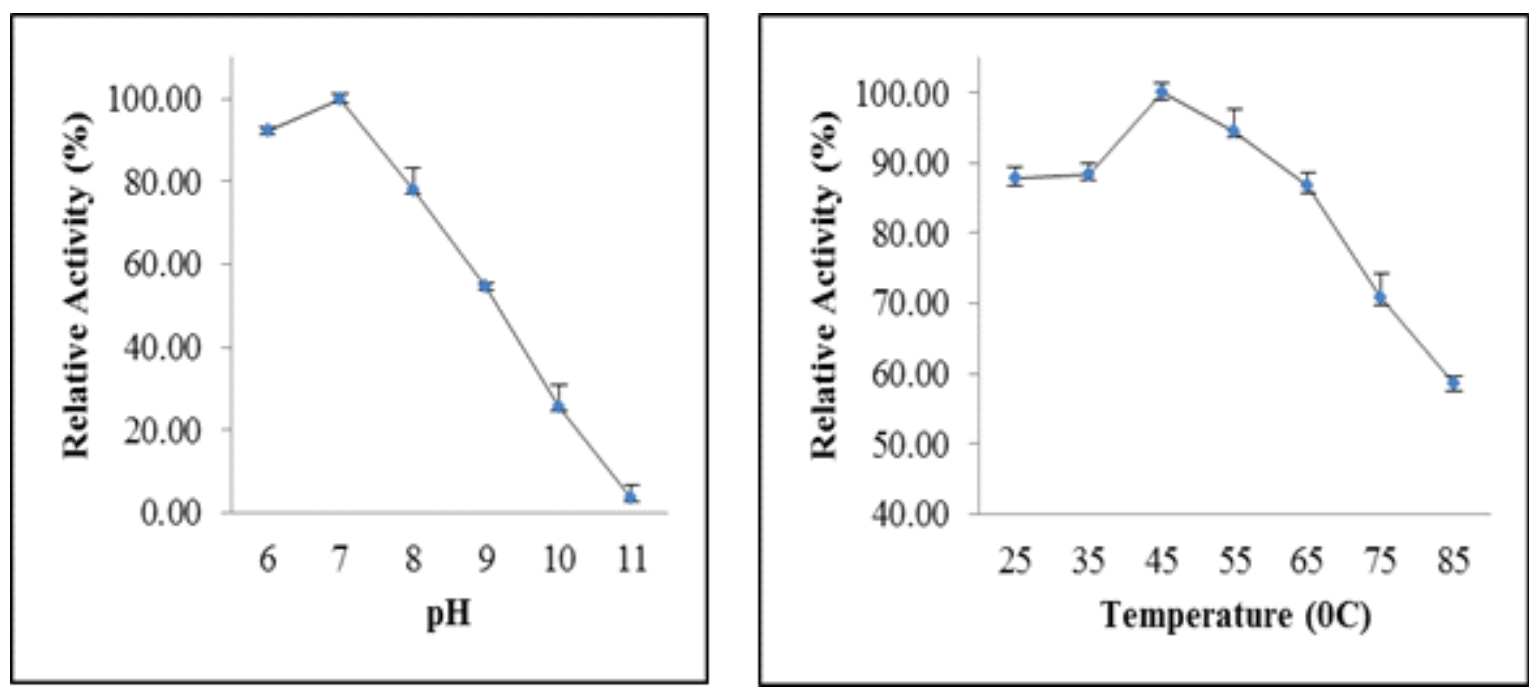

Figure 3. Activity of alginate lyase from Bacillus megaterium at various $\mathrm{pHs}(\mathrm{a})$ and at different temperature (b). The relative activity was compared to its maximum activity.

Sphingomonas sp. strain A1 (Hashimoto et al., 2000), Pseudomonas sp. QD03 (Xiao, Han, Yang, Xin-zhi \& Wen-gong, 2006), Azotobacter vinelandii (Gimmestad et al., 2009), and Corynebacterium sp (Kim et al., 2011). This research was the first finding of a new alginate lyase producing Bacillus megaterium S245. Another work that reported bacteria producing alginate lyase from genus Bacillus were Bacillus sp ATB-1015 (Nakagawa, Ozaki, Chubachi, Hosoyama \& Okubo, 1998) and Bacillus subtilis (El Ahwani \& Elborai, 2012).

\subsection{Characterization of Enzyme}

Figure 3. showed activity of alginate lyase from $B$. megaterium $\mathrm{S} 245$ at various $\mathrm{pHs}$ and temperatures. The activity was slighly increased at $\mathrm{pH}$ of 7 then gradually decreased to $\mathrm{pH}$ of 11 . At $\mathrm{pH}$, of the 11 activity of enzyme was only $3,38 \%$ compared to the highest activity at $\mathrm{pH}$ of 7 . The optimum $\mathrm{pH}$ for this enzyme was 7 with maximum activity as $8.72 \mathrm{U} / \mathrm{ml} /$ min. Other reserchers reported that optimum $\mathrm{pH}$ of alginate lyase were 7 from Vibrio sp. YKW-34 and Alteromonas sp. strain H-4 (Fu, Hong \& Kim S, 2007; Sawabe et al., 1997), 7.5 from Vibrio sp YKW-34 (Xiao et al., 2007), 7.5-8 from Alteromonas sp. strain no 272 (Iwamoto et al., 2001), and 8.5 from Pseudoalteromonas sp. SM0524 (Li et al., 2011 a).

The activity of alginase from $B$. megaterium $\mathrm{S} 245$ at different temperatures indicated an increase from $25^{\circ} \mathrm{C}$ and reach maximum at $45^{\circ} \mathrm{C}$. After that, the activity of alginat lyase was slighly down at temperature $65{ }^{\circ} \mathrm{C}$, and droped at $85{ }^{\circ} \mathrm{C}$. At this temperature, the activity of aginate lyase remained $58.62 \%$ compared to the highest activity. The minimum activity at temperature $>65^{\circ} \mathrm{C}$ showed that this enzyme was heat unstable. The optimum activity was obtained at $45^{\circ} \mathrm{C}$ reaching $9.00 \mathrm{unit} / \mathrm{ml} / \mathrm{min}$ and the minimum was at $85^{\circ} \mathrm{C}$ reaching $5.28 \mathrm{unit} / \mathrm{ml} / \mathrm{min}$. The optimum temperature for alginate lyase from Pseudomonas aeruginosa FRD1, Vibrio sp YKW-34, Pseudomonas syringae pv. Syringae, Pseudoalteromonas sp. SM0524 were respectively $37,40,42,50^{\circ} \mathrm{C}$ (Fu et al., 2007; Li et al., 2011ª; Preston, Wong, Bender \& Schiller, 2000; Xiao et al., 2006).

The zymogram insitu enzyme activity of this alginate lyase were shown in Figure 4. It showed that molecular mass of this enzyme was around $42.5 \mathrm{kDa}$. The molecular mass of this enzyme was close to alginate lyase from Pseudomonas sp. QD03 cloned into Pseudomonas aeruginosa FRD1 as 42,8 kDa (Xiao et al., 2006). Other researches reported that molecular mass of lyase from Pseudoalteromonas sp. SM0524 as $32 \mathrm{kDa}$ (Li et al., 2011'a), Vibrio sp. YKW-34 as 60 $\mathrm{kDa}$ (Fu et al., 2007), and Vibrio sp. mutant Strain 510-64 as $34.6 \mathrm{kDa}$ (Hu et al., 2006). The lowest molecular mass of this enzyme was reported as 23 $\mathrm{kDa}$ from Pseudomonas fluorescens HZJ216 ( $\mathrm{Li}$ et al., 2011'b) and from Alteromonas sp. strain 272 (Iwamoto et al., 2001).

Table 1 represent the activity of alginate lyase at different polymannuronate and polyguluronate concentrations. It showed that the enzyme activity was increased sharply with the increasing of polymannuronate concentration. The maximum enzyme activity was found at polymannuronate concentration $120 \mathrm{mg} / \mathrm{ml} 131.44 \mathrm{unit} / \mathrm{ml} / \mathrm{min}$. Using Lineweaver-Burk double reciprocal plot method, the kinetics of this lyase activity follows the equation of $Y$ $=0.339 \mathrm{X}+0.005\left(R^{2}=0.999\right)$ (Figure 5). From this 
Table 1. Activities of alginate lyase at different polymannuronate and polyguluronate concentrations as substrate

\begin{tabular}{cccc}
\hline \multicolumn{2}{c}{ Polymannuronate Substrate } & \multicolumn{2}{c}{ Polyguluronate Substrate } \\
\hline $\begin{array}{c}\text { Substrate Concentration } \\
(\mathrm{mg} / \mathrm{ml})\end{array}$ & $\begin{array}{c}\text { Enzyme Activity } \\
(\mathrm{U} / \mathrm{ml} / \mathrm{min})\end{array}$ & $\begin{array}{c}\text { Substrate } \\
\text { Concentration }(\mathrm{mg} / \mathrm{ml})\end{array}$ & $\begin{array}{c}\text { Enzyme Activity } \\
(\mathrm{U} / \mathrm{ml} / \mathrm{min})\end{array}$ \\
\hline 1 & 2,47 & 0,5 & 0,99 \\
7,5 & 19,99 & 1 & 2,32 \\
15 & 28,76 & 2,5 & 3,66 \\
30 & 43,44 & 5 & 6,07 \\
60 & 84,30 & 7,5 & 8,60 \\
120 & 131,44 & 15 & 24,18 \\
& & 30 & 27,97 \\
\hline
\end{tabular}

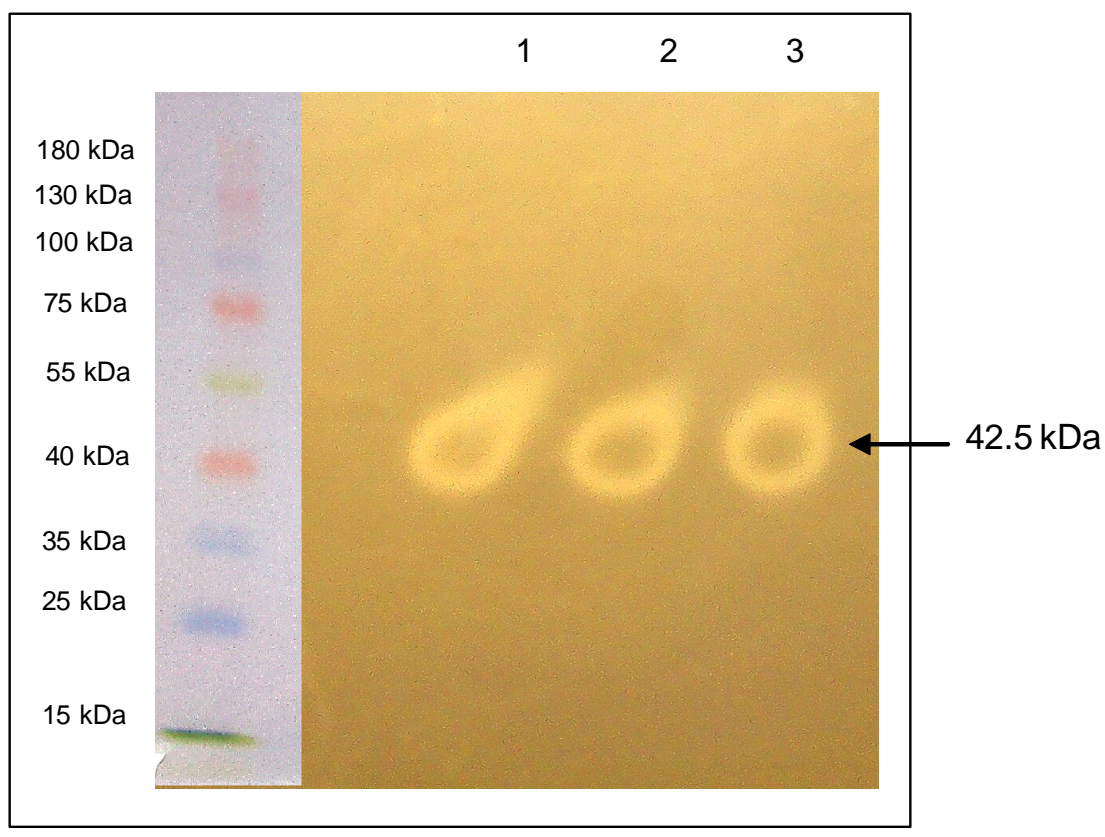

Figure 4. Zymogram of alginate lyase from B. megaterium S245. Enzyme was separated in three line (1, 2, 3 (three replication)) of $15 \%(\mathrm{~m} / \mathrm{v})$ SDS-PAGE without mercaptoethanol. $\mathrm{M}=\operatorname{marker}(15-180 \mathrm{kDa})$.

equation, $\mathrm{K}_{\mathrm{m}}$ and $\mathrm{V}_{\max }$ for polymannuronate substrate can be calculated as $79.8 \mathrm{mg} / \mathrm{ml}$ and $200 \mathrm{U} / \mathrm{ml} / \mathrm{min}$ respectively. For polyguluronate as enzyme substrate, the maximum enzyme activity was only 27.97 unit/ $\mathrm{ml} / \mathrm{min}$ at concentration substrate $30 \mathrm{mg} / \mathrm{ml}$, significantly lower compared to that of polymannuronate substrate. The kinetics of lyase activity on polyguluronate substrate follows the equation of $Y=0.475 X+0.037\left(R^{2}=0.984\right)$. Therefore, $\mathrm{K}_{\mathrm{m}}$ and $\mathrm{V}_{\max }$ for polyguluronate substrate can be calculated as $13.17 \mathrm{~g} / \mathrm{L}$ and $27.78 \mathrm{unit} / \mathrm{ml} /$ minutes respectively. Xiao, Hong and Sang, (2007) reported the $\mathrm{K}_{\mathrm{m}}$ alginate lyase from Alteromonas $\mathrm{sp}$ was 0.27 $\mathrm{mg} / \mathrm{ml}\left(6.8 \times 10^{6} \mathrm{M}\right)$. Li et al $\left(2011^{\mathrm{a}}\right)$ reported that $\mathrm{K}_{\mathrm{m}}$ of Pseudoalteromonas sp. SM0524 was $1.086 \mathrm{mg} /$ $\mathrm{ml}, 0.465 \mathrm{mg} / \mathrm{ml}$ and $2.751 \mathrm{mg} / \mathrm{ml}$ on sodium alginate, polyguluronate and polymannuronate. Two types of alginate lyase from Vibrio sp had $\mathrm{K}_{\mathrm{m}}$ value of $5.1 \times 10^{-}$ ${ }^{5}$ and $5.4 \times 10^{-5} \mathrm{M}$ (Iwamoto et al., 2001). The $\mathrm{K}_{\mathrm{m}}$ of this enzyme was higher than previous research 

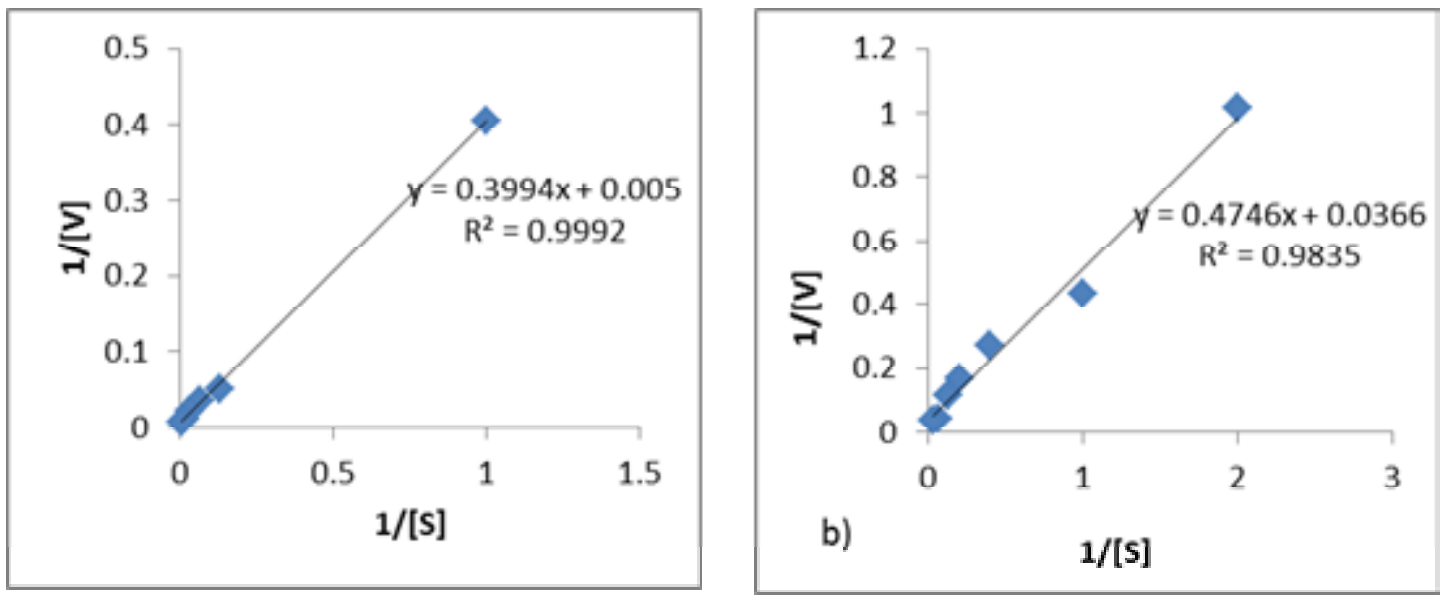

Figure 5. Lineweaver-Burke plots for the degradation of polymannuronate (a) and polyguluronate (b) by the alginate lyase produced by $B$. megaterium S245.

because the enzyme used ini this research was not purified yet.

Presently the enzyme is being applied at its optimum activity to produce bioactive oligomannuronate and oligoguluronate.

\section{Conclusion}

Based on sequence of 16 S rDNA, bacteria S245 producing alginate lyase was identified closed to $B$. megaterium (ID 96\%). Activity of this alginate lyase was optimum at $\mathrm{pH}$ of 7.0 and temperature of $45^{\circ} \mathrm{C}$. This enzyme was active toward polymannuronate substrate as well as polyguluronate susbtrates, and the $\mathrm{V}_{\max }$ and $\mathrm{K}_{\mathrm{m}}$ of this enzyme were $200 \mathrm{unit} / \mathrm{ml} / \mathrm{min}$ and $79.8 \mathrm{~g} / \mathrm{L}$ for mannuronate substrate and 27.78 unit $/ \mathrm{ml} / \mathrm{min}$ and $13.17 \mathrm{~g} / \mathrm{L}$ for guluronate substrate respectively. The apparent molecular mass of this enzyme was $42.5 \mathrm{kDa}$.

\section{Acknowledgment}

This research was supported by Research Center and Development for Marine and Fisheries Product Processing and Biotechnology, Ministry of Marine Affairs and Fisheries Indonesia.

\section{References}

An, Q.D., Wu, H.T., Zhang, Z.C., Zheng, G.S., Luan, L. \& Murata, Y. (2009). Alginate-deriving oligosaccharide production by alginase from newly isolated Flavobacterium sp. LXA and its potential application in protection against pathogens. J. Appl. Microbiol., 106(1): 161-170.

Baron, A.J., Wong, T.Y., Hicks, S.J., Gacesa, P., Willcock, D. \& Mc. Pherson, M.J. (1994). Alginate lyase from
Klebsiella pneumoniae, subsp. Aerogenes:gene cloning, secuence analysis and high-level production in Escerechia coli. Gene, 143: 61-63.

El Ahwany, A.M.D \& Elborai, A.M. (2012). Optimization of medium composition for extra cellular alginate lyases of a marine bacterium. African Journal of Microbiology Research 6(10): 2403-2409.

Fu, X.T., Hong, L. \& Kim, S.M. (2007). Purification and characterization of a $\mathrm{Na}+\mathrm{K}+$ dependent alginate lyase from turban shell gut Vibrio sp. YKW-34. Enzyme and Microbial. Technol., 41: 828-834.

Gimmestad, M., Ertesvåg, H., Heggeset, T.M.B., Aarstad, O., Svanem, B.I.G. \& Valla, S. 2009. Characterization of three new azotobacter vinelandii alginate lyases, one of which is involved in cyst germination. Journal of Bacteriology 191(15): 4845-4853.

Guo, W., Wang, Y., Song, C., Yang, C., Li, Q., Li, B., Su W., Sun, X., Song, D., Yang, X. \& Wang, S. (2011). Complete Genome of Pseudomonas mendocina NK-01, Which Synthesizes Medium-Chain-Length Polyhydroxyalkanoates and Alginate Oligosaccharides. J. Bacteriol., 193(13): 3413-3414.

Hashimoto, W., Miyake, O., Momma, K., Kawai, S. \& Murata, K. (2000). Molecular identification of oligoalginate lyase of Sphingomonas sp. strain A1 as one of the enzymes required for complete depolymerization of alginate. J. Bacteriol., 182(16): 4572-4577.

Haug, A., Larsen, B. \& Smidsrød, O. (1967). Studies on the sequence of uronic acid residues in alginic acid. Acta Chem. Scand., 21: 691-704.

$\mathrm{Hu}$, X., Jiang, X. \& Hwang, H.M. (2006). Purification and characterization of an alginate lyase from marine bacterium Vibrio sp. mutant strain 510-64. Current Microbiol., 53: 135-140.

Choi, D.B., Piao, Y.L., Shin, W.S. \& Cho, H. (2009). Production of oligosaccharide from alginate using Pseudoalteromonas agarovans. J. Appl. Biochem. Biotechnol., 159: 438-452. 
Iwamoto, M., Kurachi, M., Nakashima, T., Kim, D., Yamaguchi, K., Oda, T., Iwamoto, Y. \& Muramatsu, T. (2005). Structure-activity relationship of alginate oligosaccharides in the induction of cytokine production from RAW264.7 cells. FEBS Lett., 579: 4423-4429.

Iwamoto, Y., Araki, R., Iriyama, K., Oda, T., Fukuda, H. \& Hayashida. (2001). Purification and characterization of bifungtional alginate lyase from Alteromonas sp. strain no 272 and its action on saturated oligomeric substrate. Biosci. Biotechnol. Biochem., 65: 133-142.

Kawamoto, H., Horibe, A., Miki, Y., Kimura, T., Tanaka, K., Nakagawa, T., Kawamukai, M. \& Matsuda, H. (2006). Cloning and sequencing analysis of alginate lyase genes from the marine bacterium Vibrio sp.O2. Mar. Biotechnol., 8(5):481-490.

Khanafari, A. \& Sepahei, A.A. (2007). Alginate biopolymer production by Azotobacter chroococcum from whey degradation. International Journal of Environmental Science \& Technology 4: 427-432.

Kim, H.S., Lee, C.G. \& Lee, E.Y. (2011). Alginate lyase: Structure, property, and application. Biotechnology and Bioprocess Engineering 16: 843.

Lee, S.I, Choi, H.S, Lee, E.Y. \& Kim, H.S. (2012). Molecular cloning, purification, and characterization of a novel polyMG-specific alginate lyase responsible for alginate MG block degradation in Stenotrophomas maltophilia KJ-2. J. Appl. Microbiol. and Biotechnol., 95(6): 1643-1653.

Li, J.W., Dong, S., Song, J., Li, C.B., Chen, X.L., Xie, B.B \& Yang, Y.Z. (2011 a). Purification and Characterization of a Bifunctional Alginate Lyase from Pseudoalteromonas sp. SM0524, Mar. Drugs., 9: 109-123.

Li, L., Jiang, X., Guan, H., Wang, P. \& Guo, H. (2011 b). Three Alginate Lyases from Marine Bacterium Pseudomonas fluorescens HZJ216: Purification and Characterization. Appl. Biochem. Biotechnol., 164: 305-317.

Lishuxin, H., Jungang, Z., Qiang, P., Hong, L. \& Yuguang, D. (2013). Characterization of a new alginate lyase from newly isolated Flavobacterium sp. S20. J. Indust Microbiol and Biotechnol, 40(1), 113-122.

Matiur, R.M., Ling, W., Akira, I. \& Takao, O. (2012). cDNA cloning and bacterial expression of a PL-14 alginate lyase from a herbivorous marine snail Littorina brevicula. Carbohyd. Res., 360: 69-77.

Matsubara, Y., Iwasaki, K. \& Muramatsu, T. (1998). Action of poly ( $\alpha$-L-guluronate) lyase from Corynebacterium sp. ALY-1 strain on saturated oligoguluronates. J. Biosc. Biotechnol. Biochem., 62: 1055-1060.

Matsushima, R., Danno, H., Uchida, M., Ishihara, K., Suzuki, T., Kaneniwa, M., Ohtsubo, Y., Nagata, Y. \&
Tsuda, M. (2010). Analysis of extracellular alginate lyase and its gene from a marine bacterial strain, Pseudoalteromonas atlantica AR06 J. Appl. Microbiol. and Biotechnol., 86: 567-576.

Nakagawa, A., Ozaki, T., Chubachi, K., Hosoyama, T., \& Okubo, T. (1998). An effective method for isolating alginate lyase-producing Bacillus sp. ATB-1015 strain and purification and characterization of lyase. J. Appl. Microb., 84: 328-335.

Prasertsan, P., Wichienchot, S., Doelle, H., \& Kennedy, J.F. (2008). Optimization for biopolymer production by Enterobacter cloacae WD7. Carbohydrate Polymers 71(3): 468-475.

Preston, L.A., Wong, T.Y., Bender, C.L. \& Schiller, N.L. (2000). Characterization of Alginate Lyase from Pseudomonas syringae pv. Syringae. J. Bacteriol. 182 (21): 6268-6271.

Rasamivaraka, T., Labtani, Q., Duez, P. \& Jaziri, M.E. 2015. The formation of biofilms by Pseudomonas aeruginosa: a review of the natural and synthetic compounds interfering with control mechanisms. BioMed Research International 2015: 1-17.

Sawabe, T., Otsuka, M. \& Ezura, Y. (1997). Novel alginate lyases from marine bacterium Alteromonas sp. strain H-4. Carbohyd. Res., 304: 69-76.

Scholle, M.D., W hite, C.A., Kunnialaiyaan, M., \& Vary, P. S. (2003). Sequencing and characterization of pBM400 from Bacillus megaterium QMB1551. Appl. and Environ. Microbiol., 69(11): 6888-6898.

Subaryono, Peranginangin, R., Suhartono, M.T. \& Zakaria F.R. (2013). Alginate Lyases: Sources, Mechanism of Activity and Potencial Application. Squalen Bull. of Mar. \& Fish. Postharvest \& Biotechnol., 8 (3):105-116.

Tang, J.C., Taniguchi, H., Chu, H., Zhou, Q., \& Nagata, S. (2009). Isolation and characterization of alginatedegrading bacteria for disposal of seaweed wastes. Lett. in Appl. Microbiol., 48(1): 38-43.

Trivedi, P.C., Pandey, S. \& Bhadauria, S. (2010). Text book of microbiology. Aaviskhar Publisher., $457 \mathrm{p}$.

Wong, T.Y., Preston, L.A. \& Shiller, N.L . (2000). Alginate Lyase: Review of Major Sources and Enzyme Characteristics, Structure-Function Analysis, Biological Roles, and Applications. Annual Rev. of Microbiol., 54: 289-340.

Xiao, L., Han, F., Yang, Z., Xin-zhi, L. \& Wen-gong, Y. (2006). A novel alginate lyase with high activity on acetylated alginate of Pseudomonas aeruginosa FRD1 from Pseudomonas sp. QD03. World J. of Microbiol. \& Biotechnol., 22: 81-88.

Xiao, T.F., Hong, L. \& Sang, M.K. (2007). Purification and characterization of $\mathrm{Na}+/ \mathrm{K}+$ dependent alginate lyase from turban shell gut Vibrio sp YKW-34. Enzyme and Microbial. Technol., 41: 828-834. 